\title{
The Equal Employment Opportunity Omission
}

\author{
William Lazonick, Philip Moss, and Joshua Weitz ${ }^{*}$
}

\section{Working Paper No. 53}

\author{
December 5, 2016
}

\begin{abstract}
On June 2, 1965, under a mandate established by Title VII of the Civil Rights Act of 1964, the U.S. Congress created the Equal Employment Opportunity Commission (EEOC) to enforce federal anti-discrimination laws related to employment. The expectation was that African Americans would be prime beneficiaries of the EEOC. There was no assumption that the EEOC, on its own, could reverse deep-rooted employment discrimination against blacks. But in the late 1960s there was optimism that, in combination with equal educational opportunity and the strong demand for unionized workers in the well-paid manufacturing jobs that marked the post-World War II decades, the EEOC could help to ensure that an ever-increasing number of blacks would ascend to the American middle class.
\end{abstract}

\footnotetext{
* William Lazonick is professor of economics at University of Massachusetts Lowell and president of the Academic-Industry Research Network. Philip Moss is professor of economics at the University of Massachusetts Lowell. Joshua Weitz is a research associate at the Academic-Industry Research Network. The Academic-Industry Research Network, a 501(c)(3) research organization based in Cambridge, Massachusetts, is currently completing the "Fifty Years After" report for the Institute for New Economic Thinking.

We have written the following summary of the analytical perspective, broad findings, and policy implications of our project for INET's conference "Tomorrow's Detroits \& Detroit's Tomorrows" at Wayne State University on November 11-12, 2016. As we complete our "Fifty Years After" report, we welcome comments from conference participants (email: william.lazonick@gmail.com).
} 
African Americans as a group are better educated than they were in the 1960s, and, as discriminatory norms and practices have lessened, large numbers of college-educated blacks have experienced upward employment mobility into professional, technical, and administrative occupations. But the promise of a large-scale ascendancy of blacks to middle-class status, characterized by secure and well-paid employment, has not been fulfilled. Our basic thesis is that, in combination with the institutions of racism which remain widespread in American society, the erosion of secure and well-paid employment opportunities is a major reason for the persistence since the 1980s of African Americans as disproportionately disadvantaged. Our contribution to the larger debate on the economics of race is to focus on the role of corporate resource allocation as the prime determinant of the quantity and quality of employment opportunities in the economy. The decline of middle-class employment opportunities has adversely affected the majority of the U.S. labor force of all races, ethnicities, and genders. African Americans, however, have been more vulnerable than other demographic groups to this decline.

U.S. institutions of corporate governance vest power over major resource-allocation decisions in the hands of senior executives, supported by their hand-picked corporate boards. Given the enormous size of the major business corporations and their centrality to economic activity, the resource-allocation decisions made by senior executives of major U.S. corporations profoundly influence the operation and performance of the economy as a whole-including the availability, or not, of secure and well-paid employment opportunities. The failure to include an analysis of corporate resource allocation and how it has changed over the past half century in the policy debate on income inequality is what we call the "equal employment opportunity omission."

JEL Codes: J5, J6, J7, J8, M5

Keywords: Employment opportunity, employment relations, blue-collar workers, whitecollar workers, corporate governance, financialization, racial discrimination, African Americans, middle class, intergenerational economic mobility 


\section{The Omission}

On June 2, 1965, under a mandate established by Title VII of the Civil Rights Act of 1964, the U.S. Congress created the Equal Employment Opportunity Commission (EEOC) to enforce federal anti-discrimination laws related to employment. The expectation was that African Americans would be prime beneficiaries of the EEOC. There was no assumption that the EEOC, on its own, could reverse deep-rooted employment discrimination against blacks. But in the late 1960s there was optimism that, in combination with equal educational opportunity and the strong demand for unionized workers in the well-paid manufacturing jobs that marked the post-World War II decades, the EEOC could help to ensure that an ever-increasing number of blacks would ascend to the American middle class.

African Americans as a group are better educated than they were in the 1960s, and, as discriminatory norms and practices have lessened, large numbers of college-educated blacks have experienced upward employment mobility into professional, technical, and administrative occupations. But the promise of a large-scale ascendancy of blacks to middle-class status, characterized by secure and well-paid employment, has not been fulfilled. The persistent problem of insecure, poorly paid employment in the world's largest economy is not, however, simply an African-American problem. Since the early 1980s there has been a general erosion of the American middle class that has also attacked the living standards of the majority of whites. ${ }^{1}$

The decline of middle-class employment opportunities, however, has hit blacks as well as Hispanics much more severely than whites. When the erosion of the American middle class took hold in the 1980s, blacks and Hispanics were more vulnerable to job loss and their offspring tended to lack the social networks and financial resources to move up the employment-opportunity ladder from high-school-educated blue-collar work to collegeeducated white-collar work. Indeed, with the lower rungs of the employment-opportunity ladder cracked or broken, blacks and Hispanics were more vulnerable to falling down further into low-paid service jobs such as fast food or mass retailing, or into the massincarceration industry that boomed in the 1980s and 1990s, with many finding employment as prison guards and a far larger number becoming forced labor as prison inmates.

To simplify our analysis, and because our report focuses on what has happened to black employment in the half century since the formation of the EEOC, we compare the evolution of the employment experiences of blacks and whites. We also focus primarily but not exclusively on the employment experiences of black males. Our research also makes use of a rich source of data-EEOC employment reports filed by tens of thousands of companies

1 William Lazonick, "Labor in the Twenty-First Century: The Top 0.1\% and the Disappearing Middle Class," in Christian E. Weller, ed., Inequality, Uncertainty, and Opportunity: The Varied and Growing Role of Finance in Labor Relations, Cornell University Press, 2015: 143-192 (a pre-publication version is available for download as an INET working paper at https://www.ineteconomics.org/research/research-papers/labor-in-the-twenty-first-century-the-top-0-1-and-thedisappearing-middle-class) 
every year for the past half century-that can shed immense light on types of employment by industry and occupational category gained and lost by labor-force participants by race, ethnicity, and gender. ${ }^{2}$

Our overriding contention is that an understanding of income distribution and economic growth requires an analysis of the investment strategies, organizational structures, and financial behaviors of the business corporations that dominate economic activity. Our perspective makes issues of "corporate governance," "employment relations," and "investment finance" central to the core questions of economic analysis-including the economics of race. The vast majority of economists who are concerned with the problem of income inequality ignore the role of corporate resource allocation in determining income distribution and socioeconomic mobility. That neglect, we contend, is a cardinal mistake. The "Fifty Years After" project is part of a larger effort by the Academic-Industry Research Network to correct that intellectual error. ${ }^{3}$

Our basic thesis is that, in combination with the institutions of racism which remain widespread in American society, the erosion of secure and well-paid employment opportunities is a major reason for the persistence since the 1980s of African Americans as disproportionately disadvantaged. Our contribution to the larger debate on the economics of race is to focus on the role of corporate resource allocation as the prime determinant of the quantity and quality of employment opportunities in the economy. The decline of middle-class employment opportunities has adversely affected the majority of the U.S. labor force of all races, ethnicities, and genders. African Americans, however, have been more vulnerable than other demographic groups to this decline.

An understanding of the current problem of employment opportunity in the United States must include an analysis of the transformations in governance (or strategy), employment (or organization), and investment (or finance) at major U.S. business corporations over the past half century. In the United States, business employment represents about 81 percent of total civilian employment, and in 2012, 1,909 business enterprises with 5,000 or more employees within the United States averaged 20,488 employees and accounted for 34

\footnotetext{
${ }^{2}$ A note on these data and their uses is available from the authors.

3 William Lazonick, "Innovative Enterprise or Sweatshop Economics? In Search of Foundations of Economic Analysis," Challenge, 59, 2, 2016: 65-114. See also Lazonick, "Labor in the Twenty-First Century"; Matt Hopkins and William Lazonick, "Who Invests in the High-Tech Knowledge Base?" Institute for New Economic Thinking Working Group on the Political Economy of Distribution Working Paper No. 6, September 2014 (revised December 2014), at https://ineteconomics.org/ideas-papers/research-papers/who-invests-in-the-high-tech-knowledge-base; William Lazonick, Philip Moss, Hal Salzman, and Öner Tulum, "Skill Development and Sustainable Prosperity: Collective and Cumulative Careers versus Skill-Biased Technical Change," Institute for New Economic Thinking Working Group on the Political Economy of Distribution Working Paper No. 7, December 2014, at https://ineteconomics.org/ideaspapers/research-papers/skill-development-and-sustainable-prosperity-cumulative-and-collective-careers-versus-skillbiased-technical-change; William Lazonick, “Stock Buybacks: From Retain-and-Reinvest to Downsize-and-Distribute,” Center for Effective Public Management, Brookings Institution, April 2015, at

http://www.brookings.edu/research/papers/2015/04/17-stock-buybacks-lazonick; Matt Hopkins and William Lazonick, "The Mismeasure of Mammon: The Uses and Abuses of Executive Pay Data," Institute for New Economic Thinking Working Paper No. 49, at https://www.ineteconomics.org/research/research-papers/the-mismeasure-ofmammon-uses-and-abuses-of-executive-pay-data.
} 
percent of all business employees, 38 percent of all business payrolls, and 44 percent of all business revenues. ${ }^{4}$ The quantity and quality of employment opportunities that the U.S. economy offers, both within these large companies and in millions of smaller firms with which the large companies or their employees do business, depend heavily on the investment strategies, organizational structures, and financial behaviors of this relatively small number of larger firms.

U.S. institutions of corporate governance vest power over major resource-allocation decisions in the hands of senior executives, supported by their hand-picked corporate boards. Given the enormous size of the major business corporations and their centrality to economic activity, the resource-allocation decisions made by senior executives of major U.S. corporations profoundly influence the operation and performance of the economy as a whole-including the availability, or not, of secure and well-paid employment opportunities. The failure to include an analysis of corporate resource allocation and how it has changed over the past half century in the policy debate on income inequality is what we call the "equal employment opportunity omission."

\section{Business Models}

A business enterprise is a social organization with particular strategic, organizational, and financial characteristics that, in combination, constitute a "business model." Building on William Lazonick's analysis of the changes in corporate governance, employment relations, and investment finance in major U.S. companies since the 1960s, we focus on the distinction between the "Old Economy business model" (OEBM) and "New Economy business model" (NEBM). ${ }^{5}$ As shown in Table 1, the transition from OEBM to NEBM, which centered on the 1980s and 1990s and by the 2000s was complete, emphasized a) the strategic shift from proprietary to open technology systems, b) the transformation of employment relations from the norm of a career with one company to a career through interfirm, or interorganizational, labor mobility, and c) the unimportance of the stock market under OEBM compared with its paramount importance for attracting capital and labor to new firms under NEBM, resulting in an incessant focus of senior executives under NEBM on stock-price performance.

\footnotetext{
4 United States Census Bureau, "Statistics of U.S. Businesses," Data on “U.S., NAICS sectors, larger employment sizes” at http://www.census.gov/econ/susb/.

5 William Lazonick, Sustainable Prosperity in the New Economy? Business Organization and High-Tech Employment in the United States, W. E. Upjohn Institute for Employment Research, 2009.
} 
Table 1. Strategic, organizational, and financial characteristics of the Old Economy business model (OEBM) and New Economy business model (NEBM) compared

\begin{tabular}{|l|l|l|}
\hline $\begin{array}{l}\text { Strategy, } \\
\text { product }\end{array}$ & $\begin{array}{l}\text { OEBM } \\
\text { Enterprise growth by building on } \\
\text { internal capabilities; expansion into } \\
\text { new product markets based on } \\
\text { related technologies; geographic } \\
\text { expansion to access national and } \\
\text { international product markets. }\end{array}$ & $\begin{array}{l}\text { New firm entry into specialized } \\
\text { markets; sale of branded } \\
\text { components to systems integrators; } \\
\text { accumulation of new capabilities by } \\
\text { acquiring young technology firms. }\end{array}$ \\
\hline $\begin{array}{l}\text { Strategy, } \\
\text { process }\end{array}$ & $\begin{array}{l}\text { Corporate R\&D labs; development } \\
\text { and patenting of proprietary } \\
\text { technologies; vertical integration of } \\
\text { the value chain, at home and abroad. }\end{array}$ & $\begin{array}{l}\text { Cross-licensing of technology based } \\
\text { on open systems; vertical } \\
\text { specialization of the value chain; } \\
\text { outsourcing and offshoring }\end{array}$ \\
\hline Organization & $\begin{array}{l}\text { Secure employment: career-with- } \\
\text { one-company norm; salaried and } \\
\text { hourly employees; unions; defined- } \\
\text { benefit pensions; employer-funded } \\
\text { medical insurance in employment } \\
\text { and retirement. }\end{array}$ & $\begin{array}{l}\text { Insecure employment: interfirm } \\
\text { mobility of labor; salaried employ- } \\
\text { ees with broad-based stock options; } \\
\text { non-union; defined-contribution } \\
\text { pensions; employee bears greater } \\
\text { burden of medical insurance. }\end{array}$ \\
\hline Finance & $\begin{array}{l}\text { Venture finance from personal } \\
\text { savings, family, and business } \\
\text { associates; NYSE listing; payment of } \\
\text { steady dividends; growth finance } \\
\text { from retentions leveraged with } \\
\text { bond issues. }\end{array}$ & $\begin{array}{l}\text { Organized venture capital; initial } \\
\text { public offering on NASDAQ; low or } \\
\text { no dividends; growth finance from } \\
\text { retentions plus stock as an } \\
\text { acquisition currency; stock } \\
\text { buybacks to support stock price. }\end{array}$ \\
\hline
\end{tabular}

Source: Lazonick, Sustainable Prosperity in the New Economy?, p. 17.

\section{From Retain-and-Reinvest to Downsize-and-Distribute}

OEBM provided the productive foundation for NEBM. Especially in high-technology industries, innovative goods and services could not have been generated under NEBM without the accumulation of productive capabilities that had occurred under OEBM, under which massive government investments in physical infrastructure and the high-tech knowledge base supported business enterprises in developing and utilizing productive capabilities. ${ }^{6}$ Given the importance of the stock market to attracting capital and labor under NEBM, however, the transformation from OEBM to NEBM also gave credence to a new ideology of corporate governance known as "maximizing shareholder value." Legitimized by shareholder-value ideology and incentivized by stock-based pay, from the 1980s senior executives of Old Economy companies increasingly replaced the "retain-and-reinvest" corporate resource-allocation regime with a regime of "downsize-and-distribute." 7 The retain-and-reinvest regime had formed the foundation for creating the employment

\footnotetext{
${ }^{6}$ Hopkins and Lazonick, "Who Invests in the High-Tech Knowledge Base?"

${ }^{7}$ William Lazonick and Mary O'Sullivan, "Maximizing Shareholder Value: A New Ideology for Corporate Governance," Economy and Society, 29, 1, 2000: 13-35; Lazonick, "Stock Buybacks."
} 
opportunities that sustained an American, albeit overwhelmingly white male, middle class in the post-World War II decades. Under a downsize-and-distribute regime, since the 1980s American workers of all races, ethnicities, and genders have faced the decimation of secure and well-paid employment opportunities. In the name of maximizing shareholder value, downsize-and-distribute has become an increasingly pervasive, and now almost unquestioned, corporate resource-allocation regime.

Under the retain-and-reinvest regime that characterized OEBM, senior executives would make corporate resource-allocation decisions that, by retaining people and profits in the company, permitted reinvestment in the productive capabilities that could generate competitive (high-quality, low-cost) products. ${ }^{8}$ The social foundation of retain-and-reinvest was employment relations that offered decades-long job security, in-house promotion opportunities, rising real earnings, and health-insurance coverage, with a defined-benefit pension at the end of a long career. In the immediate post-World War II decades, it was mainly white households that enjoyed secure and well-paid employment under OEBM, with, for both blue-collar and white-collar workers, a "career with one company" as the employment norm. The retain-and-reinvest regime combined with the career-with-onecompany norm to enable both white-collar and blue-collar workers to join a growing middle class. Especially in the 1960s and 1970s, substantial numbers of African-American households were able to access career-with-one-company employment.

\section{The Career-with-One-Company Norm}

For blue-collar workers, the career-with-one-company norm was rooted in union representation and its seniority principle of "first hired, last fired." In the aftermath of World War II, mass-production unions enabled blue-collar workers with high-school educations (and in many cases not even that) to secure the realistic promise of career employment with one company with wages and benefits that could support a middle-class standard of living over decades of work and retirement. In the 1950s, the people occupying these positions were overwhelmingly white males, although in industries such as automobiles, electronics, and steel in which mass-production unions encouraged black membership, African Americans had begun to make progress in accessing these middleclass jobs.

In white-collar professional, technical, and administrative positions, the dominance of white males, increasingly college-educated, was even more complete. These white-collar employees also had the expectation of a career with one company even in the absence of union representation, which was virtually non-existent among these "managerial" personnel. When a company invested money in training a white-collar male employee who exhibited dedication to the organization, it then sought to retain him through the prospect of promotion and the promise of a defined-benefit pension after, typically, thirty years of

\footnotetext{
8 William Lazonick, "The Theory of Innovative Enterprise: Foundation of Economic Analysis," AIR Working Paper, August 2015, at www.theAIRnet.org
} 
service. In his 1956 best-seller, Fortune magazine editor William H. Whyte called this species of white-male American "the organization man."

In the business sector, college-educated women, also predominantly white, were mainly employed in clerical work. The prevailing expectation was that once they got married they would leave the company to raise a family. Women also faced discrimination in gaining access to professional degrees; for example, it was only in 1964 that Harvard Business School first admitted women to its MBA program-and even then with great caution. ${ }^{10}$ Under the Civil Rights Act of 1964 and the EEOC, career-with-one-company employment opportunities began opening up for college-educated women as well, but within companies they hit up against "glass ceilings" that put limits on their upward mobility. Even in the late 1980s, a much-publicized debate ensued when an article in Harvard Business Review argued that, in balancing family life and work life, corporate women would be best served by being on a "mommy track" in pursuing a career within a company. ${ }^{11}$

By the late 1980s, however, the Old Economy norm of a career with one company was under severe pressure, and by the 2000s this employment relation had become a historical curiosity rather than the foundation of a highly successful business model and a thriving middle class. In the postwar decades, large numbers of African-American men had moved into secure and well-paid blue-collar jobs under OEBM, doing semiskilled work in massproduction industries such as automobiles, electronics, and steel. The main beneficiaries of OEBM were white males, but, in the presence of non-discriminatory unions, affirmativeaction legislation, and retain-and-reinvest resource-allocation regimes in the 1960 s and 1970s, blacks made significant progress in ascending to the middle class through bluecollar employment under OEBM.

The demise of OEBM in the 1980s and 1990s, however, reduced the chances for the offspring of blue-collar blacks the opportunity to make the intergenerational transition to secure and well-paid white-collar employment requiring a college education that white males had experienced in earlier decades, when OEBM dominated. That meant that whites as a group were better positioned to respond to the demise of OEBM in the 1980s and 1990s by building social networks to take advantage of employment opportunities for college-educated personnel under NEBM. But for blacks as a group, who had not made this intergenerational transition under OEBM as the dominant U.S. business model, the demise of OEBM and the rise of NEBM meant that, even with a college education, immense barriers to building the social networks required for intergenerational upward mobility were in place.

From the 1980s, the employment opportunities of all members of the U.S. labor force with no more than high-school educations were adversely affected by three transformations in

\footnotetext{
9 William H. Whyte, The Organization Man, Simon \& Schuster, 1956.

10 Elizabeth M. Fowler, “Harvard Business School goes coed with Ivy aplomb," New York Times, February 21, 1964, p. 39.

11 Felice N. Schwartz, "Management Women and the New Facts of Life," Harvard Business Review, January-February 1989: 65-76; Tamar Lewin, “'Mommy career track' sets off a furor," New York Times, March 8, 1989.
} 
employment relations that we call "rationalization," marketization," and "globalization." From the early 1980s, rationalization, characterized by plant closings and permanent layoffs, terminated the jobs of high-school-educated blue-collar workers, most of them well-paid union members. From the early 1990s, marketization, characterized by the end of a career with one company as an employment norm, placed the job security of middle-aged white-collar workers, most of them college educated, in jeopardy. From the early 2000s, globalization, characterized by an acceleration of the movement of employment offshore to lower-wage nations and the movement to the United States of foreign workers, vast numbers of whom were college-educated, left all members of the U.S. labor force, whatever their educational credentials and work experience, vulnerable to displacement. ${ }^{12}$

\section{Rationalization}

In the 1980s the onslaught on OEBM was mainly at the blue-collar level as U.S. companies faced formidable Japanese competition in industries such as automobiles, consumer electronics, steel, machine tools, and memory chips-all of them industries in which U.S. companies had previously been world leaders. The prime source of Japanese competitive advantage was their leading companies' investments in the skills of blue-collar workers and their integration of these shop-floor workers with managers and engineers in the companies' organizational learning processes. In contrast to Japanese investment in, and integration of, the skills of blue-collar workers, U.S mass-production companies had a long history of segmenting blue-collar workers from the processes of organizational learning, confining collective and cumulative learning to professional, technical, and administrative employees within corporate managerial structures. ${ }^{13}$ When confronted by Japanese competition, the hierarchical segmentation of workers from managers proved to be the Achilles heel of U.S.-style OEBM.

In effect, the Japanese won out in global competition in these mass-production and related capital-goods industries by perfecting OEBM through the extension of organizational learning from the managerial structure to operatives on the shop floor. A common contention is that automation is responsible for the demise of blue-collar employment in the United States, as robots replaced workers. In fact, it was Japanese companies, in which male blue-collar workers had employment security through the norm of permanent (or lifetime) employment, that were (and remain) the world leaders in the development and utilization of robotics, as collective and cumulative learning integrated the skills and efforts of engineers and operatives. From the 1980s the Japanese introduced automated machinery to improve product quality and reap economies of scale, and in the process put the less automated plants of their U.S. competitors out of operation or at least severely cut into their market shares.

\footnotetext{
12 Lazonick, "Labor in the Twenty-First Century."

13 William Lazonick, Competitive Advantage on the Shop Floor, Harvard University Press, 1990; William Lazonick, "Organizational Learning and International Competition," in Jonathan Michie and John Grieve Smith, eds., Globalization, Growth, and Governance, Oxford University Press, 1998: 204-238.
} 
In the first half of the 1980s the result of Japanese competition was widespread permanent layoffs and plant closings in the United States, with blacks - who tended to be last hired and, under union seniority rules, first fired-bearing the disproportionate brunt of the job losses. Permanent layoffs and plant closings continued through the second half of the decade and beyond. From 1985 the Japanese companies launched automobile plants in the United States but, with the exception of Mazda, which opted for Flat Rock, Michigan, they located these plants in greenfield plants in rural areas, employing few if any African Americans. At the same time U.S. plant closings and downsizings continued unabated, with the widespread loss of what had been middle-class jobs for high-school-educated workers.

The data that we have assembled for the "Fifty Years After" report support the argument that, in the 1980s and beyond, rationalization nullified the important gains that blacks had made in accessing secure blue-collar employment under OEBM. Industry studies and census data indicate that in the 1960s and 1970s there was significant movement of blacks from low-skill and relatively low-paid, though secure, service jobs to better-paid and secure semiskilled employment (but not to skilled craft jobs). Many of these new mass-production jobs were in new plants in suburban locations, leading black families to move out of the inner cities to access them. Thomas Sugrue has shown for the case of Detroit that access to secure and well-paid employment had eluded inner-city blacks going back to the 1950s, with the widespread decline of blue-collar employment opportunities from the 1980s making a bad situation worse. ${ }^{14}$

Even during the "stagflation" of the 1970s, it remained the practice of U.S. mass-production corporations to lay off workers in a downturn but to re-employ these workers in the next upturn. During the layoffs, displaced union workers would receive government unemployment benefits that were supplemented by the union to maintain living standards. In the 1970s, most union workers remained protected from inflation by collectively bargained cost-of-living allowances. Beginning with the double-dip recession of 19801982, however, it was increasingly the case that, with the rationalization of OEBM employment, displaced blue-collar workers did not get re-employed. Blue-collar job losses, and the decline of business-sector unionization, continued even after the economic recovery began in 1983, with blacks who had held these jobs disproportionately finding that, to paraphrase William Julius Wilson, ${ }^{15}$ work had disappeared.

\section{Marketization}

If rationalization decimated the career-with-one-company norm in blue-collar employment from the early 1980s, a process of "marketization" had a similar impact on white-collar employment under OEBM from the early 1990s-but with different employment outcomes. The U.S. corporation that was in the vanguard of marketization, as it pursued an explicit business strategy of making the transition from OEBM to NEBM, was IBM, by far the world's leading computer company at the time. Coming into the 1990s IBM touted its

\footnotetext{
14 Thomas J. Sugrue, The Origins of the Urban Crisis, Princeton University Press, 1996.

15 William Julius Wilson. When Work Disappears: The World of the New Urban Poor, Vintage Books, 1996.
} 
system of lifelong employment, bragging that the company had not laid off any employees involuntarily since 1921. But, seeking to rid itself of older workers and the career-withone-company employment relations that characterized OEBM, between 1990 and 1994 IBM slashed its employment from 374,000 to 220,000 . At that point, IBM's management had rendered the norm of a career with one company a relic of the past. In all other respects, by the mid-1990s IBM made the transition from OEBM to NEBM. ${ }^{16}$

One factor that precipitated this change at IBM was the sharp shift away from proprietary technology systems that favored the ongoing training, retention, and promotion of experienced employees who could be integral to broad and deep processes of collective and cumulative learning that proprietary systems required. The technology shift was to open systems that favored the employment of younger college-educated workers trained in the latest computer-related skills and with employment experience at rising New Economy high-tech companies. IBM was well-positioned to make this transition because of its central role in creating open systems with the overwhelming success in the 1980s of the IBM PC in making the Intel microprocessor and the Microsoft operating system the industry standards. In addition, under OEBM IBM had always been a leader in providing software and services along with hardware, and from the mid-1990s IBM shed its Old Economy hardware businesses. During the 1990s Old Economy companies followed IBM's lead in ridding themselves of the career-with-one-company norm, and by the 2000s this once pervasive corporate employment institution had given way to, as a defining characteristic of NEBM, "employability" of the white-collar worker through interorganizational labor mobility over the course of his or her career.

In the evolution of NEBM, the stock market played a major role in not only new-firm formation but also the marketization of employment relations. In 1971, just three years after it was founded, Intel was the first company to list on NASDAQ, the electronic stock market that, linking the previously fragmented local over-the-counter markets, made it possible for a very young company, with few if any profits, to do a highly lucrative initial public offering (IPO) on a highly liquid yet highly speculative stock market. The existence of NASDAQ attracted venture capital to fund these startups because the private-equity investors now had the possibility of exiting their investments in only three to five years-a time-frame that was not possible on the Old Economy New York Stock Exchange with its elevated profitability and capitalization listing requirements.

In 1971, in the same year that NASDAQ was launched, a local journalist dubbed the emerging high-tech district around Stanford University "Silicon Valley" because of the proliferation of startups like Intel producing integrated circuits using silicon as the semiconductor material. Ready to provide finance to these Silicon Valley startups was a newly formed venture-capital industry that in 1973 spawned the National Venture Capital Association (NVCA). In the late 1970s, the NVCA lobbied successfully to lower the capitalgains tax rate, which had reached an all-time high of almost 40 percent in 1976, and in 1979 NVCA lobbying convinced the U.S. Department of Labor to issue a clarification of the

16 Lazonick, Sustainable Prosperity in the New Economy?, ch. 2. 
1974 Employee Retirement Income Security Act (ERISA), now declaring that it was prudent for a pension-fund manager to allocate up to five percent of a fund's assets to risky investments such as a venture-capital fund. With this clarification protecting pension-fund managers from potential legal liability for making risky portfolio investments, pensionfund money from Old Economy companies flowed freely to venture-capital firms, becoming a flood of cash when the hugely lucrative 1980 IPOs of Apple in microelectronics and Genentech in biotechnology enabled venture capitalists that backed these companies to reap huge stock-market rewards on their private-equity investments. The 1980s and 1990s saw the proliferation venture-backed high-tech startups and IPOs in Silicon Valley, Boston's Route 128, and a number of other high-tech districts, feeding the growth of NEBM, with a focus on information-and-communication technology (ICT) and biopharmaceuticals. ${ }^{17}$

In the 1980s these knowledge-based startups needed to lure scientists, engineers, and managers from career-with-one-company security at Old Economy corporations to work for companies that might go out of business the following month or the following year, and hence could not possibly hold out a credible expectation of a career with one company. Instead of employment security, the startups offered recruits stock options, which could become extremely valuable if and when the company were able to do an IPO. As some of these New Economy companies (including Intel, Microsoft, Apple, Oracle, Sun Microsystems, Cisco Systems, and Dell in ICT, and Genentech, Biogen, Amgen, and Genzyme in biopharma) grew to employ thousands and then tens of thousands of people in the 1980s and 1990s, they continued to use stock options, in some cases supplemented by defined-contribution pensions, to attract and retain a broad base of high-tech personnel. These employees received good salaries from these companies, but the potential rewards from stock-based pay could multiply their total remuneration, and hence the performance of the company's stock price became central to employment relations under NEBM.

Increasingly, leading Old Economy companies-among them AT\&T (and after 1996 Lucent Technologies and NCR), Hewlett-Packard, IBM, Motorola, Texas Instruments, and Xerox in ICT, and Johnson \& Johnson, Merck, Pfizer, Eli Lilly, and Bristol-Myers Squibb in pharmafound that they would train young employees but then be unable to retain them when in competition with NEBM, thus eroding the rationale for a career with one company. Especially once IBM had made the transition from OEBM to NEBM in the early 1990s, over the next decade one Old Economy company after another followed suit, rewarding a broader base of employees with stock options in addition to normal salaries and putting an end to the career-with-one-company employment norm.

Particularly within managerial structures, career-with-one-company employment had been a white-male enclave. With the transition to NEBM employment relations, white males continued to dominate as they built new types of social networks in educational institutions, industrial sectors, professional associations, and industrial regions to facilitate the interorganizational mobility needed to build careers. Having been largely excluded

\footnotetext{
17 Lazonick, Sustainable Prosperity in the New Economy?, ch. 4; William Lazonick and Öner Tulum, "US Biopharmaceutical
} Finance and the Sustainability of the Biotech Business Model," Research Policy, 40, 9, 2011: 1170-1187. 
from the career-with-one-company club that characterized OEBM managerial structures, however, college-educated blacks, Hispanics, and women were poorly positioned to build these networks with the transition from OEBM to NEBM. The results of the lack of social networks (often called "social capital") under NEBM are clear in the data on the meager representation of blacks, Hispanics, and women in STEM (science, technology, engineering, mathematics) and finance occupations. ${ }^{18}$

\section{Globalization}

While in the transition from OEBM to NEBM, rationalization transformed blue-collar employment and marketization transformed white-collar employment, the globalization of employment relations increased the job insecurity inherent in both. The globalization of employment relations occurs both through international flows of productive investment to jobs and of jobs to productive investment. In the flow of investment to jobs, a company based in one country engages in foreign direct investment (FDI) or long-term subcontracting relations in another country. In the flow of jobs to investment, workers in one country migrate abroad to find employment in another country. ${ }^{19}$

Under OEBM, with its proprietary technology systems, FDI in manufacturing generally took the form of vertically integrated facilities for production and distribution of products in developed economies in cases in which there was an economic advantage to being in close proximity to customers and/or jumping tariff walls. Under NEBM, with its open technology systems, FDI in manufacturing has generally taken the form of offshoring of certain activities in the company's vertical "value chain" to reap the economic advantage of lowwage labor and/or gain access to high-quality labor.

Increasingly, these global value chains have involved developing economies. And increasingly the offshored activity is outsourced to a subcontractor rather than being carried out in a foreign facility that the company owns. In some industries and activities, the quality of foreign labor is more important than low wages in the globalization decision, while political stability of the host country and the absence of militant unions are always important to the choices of locations in which to construct global value chains. Particularly in the ICT industries, East Asian nations have become dominant in the global value chains that U.S-based companies have built. India stands out as a South Asian nation that provides information-technology services, making use of college-educated labor. But for lack of adequate investments in physical infrastructure and a literate blue-collar labor force, India has never been an important location for FDI or subcontracting in manufacturing.

Under OEBM, there was of course substantial migration of foreign nationals with varied education levels to the United States from around the world for economic and political reasons. But a dominant feature of NEBM has been the extent to which U.S.-based companies have had access to large supplies of college-educated Asian labor. The

\footnotetext{
18 See Lazonick et al, "Skill Development and Sustainable Prosperity."

${ }^{19}$ Lazonick, Sustainable Prosperity in the New Economy?, ch. 5.
} 
availability of Asian labor in the United States is not the result of free-market forces. The large supplies of college-educated Asian labor resulted from national development policies that included broad and deep investments in the education of their populations, both male and female, well ahead of demand.

From the 1960s, these educational investments resulted in brain drain from countries like South Korea and Taiwan, with the United States as the prime beneficiary. Many of these migrants obtained higher degrees in the United States and became citizens. The governments of South Korea and Taiwan had active policies to reverse the brain drain; South Korea's success in doing so by the late 1980s is evident in a 1989 Wall Street Journal article on the return to Korea of scientists and engineers, with the headline "Costly exports: Reverse 'brain drain' helps Asia but robs U.S. of scarce talent."20

With the Immigration Act of 1990, the United States gave favored treatment to collegeeducated Asians both as immigrants with permanent-resident status and on greatly expanded temporary H-1B and L-1 visas on which they could work in the United States for as many as seven years, after which it was possible to become a permanent resident. With high concentrations of these migrants to the United States in computer-related fields, college-educated Asians were able to build their own social networks for career building in the United States. In contrast with whites and Asians, college-educated blacks and Hispanics have not had the critical mass of people able and willing to pursue STEM careers who could use race and ethnicity as a basis for the social networking essential to career building. 21

A prime reason East Asian nations had high concentrations of young people with college degrees in computer-related fields by the 1990s was that in ICT industries most U.S. NEBM companies eschewed investments in routine manufacturing operations in the United States, offshoring these operations to Asia. Already by 1970 virtually every important U.S. semiconductor company was doing assembly and testing in Asia, where they found supplies of low-wage but highly literate female operatives as well as college-educated indigenous managers and engineers to run the plants. New Economy companies such as Cisco, Dell, and Apple outsourced hardware fabrication, assembly, and testing to contract manufacturers known as electronic manufacturing service providers, which even when they were based in the United States, as in the cases of Solectron, Sanmina SCI, and Jabil Circuit, increasingly located their operations in Asia. As a result, NEBM did not create many new manufacturing jobs in the United States, and certainly not ones that created the types of semiskilled employment opportunities that had previously enabled high-schooleducated blue-collar workers to attain middle-class living standards under OEBM.

In industries such as automobiles in which semiskilled work has remained in the United States, union power has diminished and wages are depressed. High-school-educated

\footnotetext{
${ }^{20}$ Stephen Kreider Yoder, “Costly exports: Reverse 'brain drain' helps Asia but robs U.S. of scarce talent,” Wall Street Journal, April 18, 1989.

21 Lazonick, Sustainable Prosperity in the New Economy?, ch. 5.
} 
members of the labor force, who would have had middle-class living standards under OEBM, have been crowded into fast-food and mass-retailing employment that cannot be offshored. Blacks with high-school educations are disproportionately represented among the "working poor" in these occupations. ${ }^{22}$ In the new global economy, the semiskilled jobs that can support a middle-class living standard have long since vanished. But that does not mean that the low wages and lack of benefits that now prevail in these occupations should be as meager as they are. Nor should it mean that we should run an economy in which large groups of people have scant prospects of intergenerational progress in education, earnings, and accessing stable career employment. These arguments bring us back to what we have called the "equal employment opportunity omission": the failure of government policy to recognize the centrality of corporate resource-allocation regimes to the availability of secure and well-paid employment for members of the U.S. labor force, and indeed to the achievement of stable and equitable growth in the economy as a whole.

\section{Financialization}

We have argued that in the post-World War II decades, the guiding principles of corporate resource allocation can be summed up as "retain-and-reinvest." 23 Business corporations retained earnings and reinvested them in productive capabilities, including the capabilities of employees who, in helping to make the enterprise more productive and competitive, benefited in the forms of higher incomes and more employment security. Retain-andreinvest is a resource-allocation regime that supports value creation at the business level and implements a process of value extraction through which the firm shares the productivity gains with a broad base of employees.

Figure 1a shows that from the late 1940s to the late 1970s changes in real wages tracked changes in productivity in the U.S. economy. ${ }^{24}$ In our view, the retain-and-reinvest employment policies of major U.S. corporations largely accounted for this result. The sharing of the gains of productivity growth with career employees, including among them both unionized blue-collar workers with high-school educations and non-unionized whitecollar workers with college educations, underpinned the resultant trend toward greater income equality in the United States from the late 1940s well into the 1970s.

\footnotetext{
22 William Lazonick, Philip Moss, and Joshua Weitz, "Employment and Earnings of African Americans" draft of the statistical overview section of the "Fifty Years After" project, November 9, 2016.

${ }^{23}$ Lazonick and O’Sullivan, "Maximizing Shareholder Value".

24 The widening gap between productivity growth and pay growth was first observed in Lawrence Mishel and Jared Bernstein. The State of Working America 1994-1995, Routledge, 1995. See also Economic Policy Institute, "The Productivity-Pay Gap," August 2016 at http://www.epi.org/productivity-pay-gap/.
} 
Figure 1a. Cumulative annual percent changes in productivity and real wages in the United States, 1948-1983

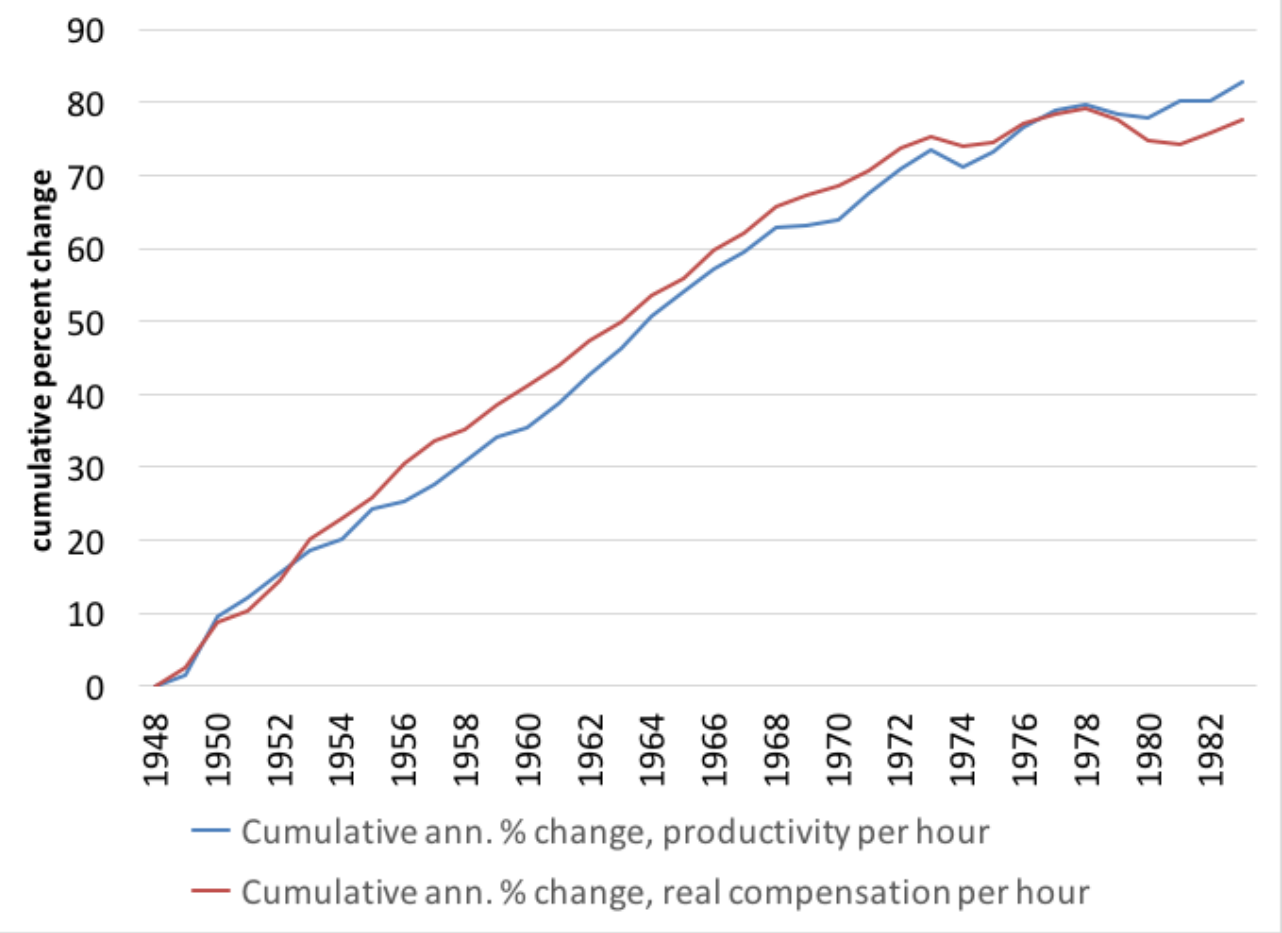

Source: http://www.econdataus.com/wagegap12.html

Figure 1b. Cumulative annual percent changes in productivity and real wages in the United States, 1963-2015

120

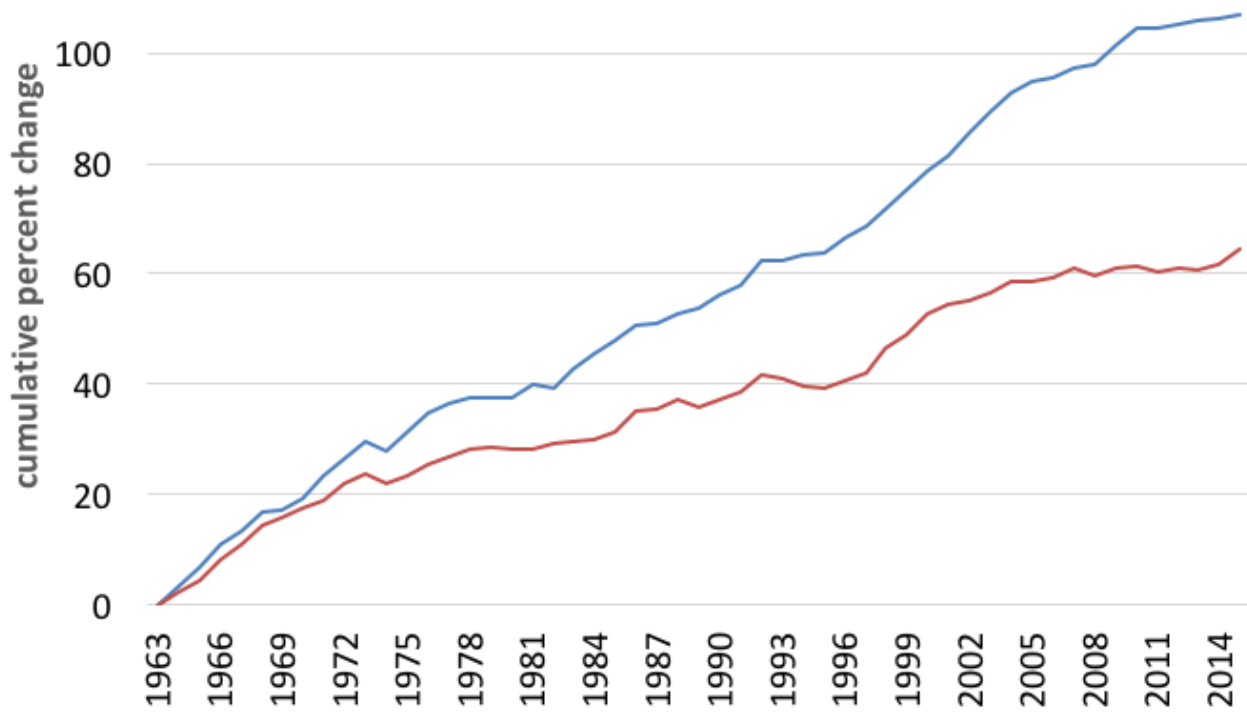

- Cumulative ann. \% change, productivity per hour

- Cumulative ann. \% change, real compensation per hour

Source: http://www.econdataus.com/wagegap12.html 
As shown in Figure 1b, however, since the late 1970s there has been a widening gap between the growth in productivity and the growth in real wages. This gap, we argue, is largely the result of a shift of corporate resource allocation to a downsize-and-distribute regime in which corporate executives look for opportunities to downsize the labor force and distribute earnings to shareholders. Had corporate executives made different allocation decisions, a portion of the earnings that were paid out to shareholders could have been invested in, among other things, the productive capabilities of the people thrown out of work. Downsize-and-distribute is a resource-allocation regime that supports value extraction at the business level that may enrich financial interests at the expense of employees who contributed to the process of value creation that generated those earnings in the first place. As a result, a downsize-and-distribute allocation regime contributes to employment instability and income inequity.

As we have seen, since the beginning of the 1980s, employment relations in U.S. industrial corporations have undergone three major structural changes, which we have summarized as rationalization, marketization, and globalization, that have permanently eliminated a large portion of middle-class jobs in the United States. Initially, each of these structural changes in employment could be justified as a business response to major changes in industrial conditions related to technologies, markets, and competitors. During the onset of the rationalization phase in the early 1980s, plant closings and permanent layoffs were a reaction to the superior productive capabilities of Japanese competitors in consumerdurable and related capital-goods industries that employed significant numbers of unionized blue-collar workers. ${ }^{25}$ During the onset of the marketization phase in the early 1990s, the erosion of the career-with-one-company norm among white-collar workers was a response to the dramatic technological shift from proprietary systems to open systems, integral to the microelectronics revolution. This shift favored younger workers with the latest computer skills, acquired in higher education and transferable across companies, over older workers with many years of company-specific experience with proprietary technologies and systems integration. During the onset of the globalization phase in the early 2000s, the sharp acceleration in the offshoring of jobs was a response to the emergence of large supplies of highly capable, and lower-wage, labor in developing nations such as China and India which, linked to the United States through inexpensive communications systems and global value chains, could take over U.S. employment activities that had become routine, and increasingly some that are more complex. ${ }^{26}$

Once U.S. corporations had transformed their employment relations, however, they often pursued rationalization, marketization, and globalization to cut current costs rather than to reposition themselves to produce competitive products. That is, they closed manufacturing plants, terminated experienced workers, and offshored production to low-wage areas of the world simply to increase profits, often at the expense of the companies' long-term

\footnotetext{
25 William Lazonick, "Innovative Business Models and Varieties of Capitalism: Financialization of the U.S. Corporation," Business History Review, 84, 4, 2010: 675-702.

26 Lazonick, Sustainable Prosperity in the New Economy?, chs. 2-5.
} 
competitive capabilities and without regard for displaced employees' long years of service. As this new approach to corporate resource allocation became embedded in the new structure of U.S. employment, business corporations failed to invest in new, higher-valueadded capabilities on a sufficient scale to create middle-class employment opportunities that could provide a new foundation for stable and equitable growth in the U.S. economy.

On the contrary, from the mid-1980s, with superior corporate performance defined as meeting Wall Street's expectations for ever-higher quarterly earnings per share, companies turned to massive stock repurchases to "manage" their own corporations' stock prices. Trillions of dollars that could have been spent on innovation and job creation in the U.S. economy over the past three decades have instead been used to buy back stock for the purpose of manipulating stock prices. For the decade 2006-2015, U.S. corporations' total net equity issues-new share issues less shares taken off the market through buybacks and merger-and-acquisition deals-averaged minus $\$ 416$ billion per year. ${ }^{27}$ Over the decade 2006-2015, the 459 companies in the S\&P 500 Index in January 2016 that were publicly listed over the decade expended $\$ 3.9$ trillion on stock buybacks, representing 53.6 percent of net income, plus another 36.7 percent of net income on dividends. ${ }^{28}$ Much of the remaining 9.7 percent of profits was held abroad, sheltered from U.S. taxes. Many of America's largest corporations routinely distribute more than 100 percent of net income to shareholders, generating the extra money by reducing cash reserves, selling off assets, taking on debt, or laying off employees. ${ }^{29}$

Legitimizing this financialized mode of corporate resource allocation has been the ideology, itself a product of the 1980s and 1990s, that a business corporation should be run to "maximize shareholder value."30 Through their stock-based compensation in the forms of stock options and stock awards, corporate executives who make these decisions are themselves prime beneficiaries of this focus on rising stock prices as the sole measure of corporate performance. Over the decade 2006-2015, the average total annual remuneration of the 500 highest-paid corporate executives in the United States ranged from a low of $\$ 14.7$ million in 2009 , when the stock market was down and stock-based pay made up 66 percent of the total, to a high of $\$ 32.2$ million in 2015 , when stock-based pay came to 84 percent of the total. ${ }^{31}$ For the sake of this remuneration, these executives have

27 Board of Governors of the Federal Reserve System, Federal Reserve Statistical Release Z.1, "Financial Accounts of the United States: Flow of Funds, Balance Sheets, and Integrated Macroeconomic Accounts," Table F-223: Corporate Equities, December 10, 2015, at http://www.federalreserve.gov/releases/z1/current/.

${ }^{28}$ Calculations from the stock-buyback database of the Academic-Industry Research Network, constructed and maintained by Mustafa Erdem Sakinç and Emre Gomeç.

${ }^{29}$ Lazonick, "Labor in the Twenty-First Century"; William Lazonick, "How Stock Buybacks Make Americans Vulnerable to Globalization," paper presented at the Workshop on Mega-Regionalism: New Challenges for Trade and Innovation, EastWest Center, University of Hawaii, Honolulu, January 20, 2016, at http://papers.ssrn.com/sol3/papers.cfm?abstract_id=2745387

30 Lazonick and O’Sullivan, "Maximizing Shareholder Value"; William Lazonick, "Innovative Enterprise and Shareholder Value," Law and Financial Markets Review, 8, 1, 2014: 52-64.

31 Hopkins and Lazonick, "The Mismeasure of Mammon"; Matt Hopkins and William Lazonick, "Corporate executives are making way more money than anyone reports," The Atlantic, September 15, 2016, at http://www.theatlantic.com/business/archive/2016/09/executives-making-way-more-than-reported/499850/ 
been engaged in downsize-and-distribute resource allocation that amounts to nothing less than the looting of the U.S. business corporation.

As a result of rationalization, marketization, and globalization, the paucity of secure and well-paid employment opportunities in the U.S. economy is largely structural. But the structural problem is not, as some economists have argued, a labor-market mismatch between the skills that prospective employers want and the skills that potential workers have. ${ }^{32}$ If major employers need and want a match, they can train and then, through pay, promotion, and benefits, retain employees. That, in fact, was the primary reason why U.S. business corporations adopted the norm of a career with one company for white-collar workers under OEBM. For innovative companies, the match between the skills that employers demand and the skills that employees can supply is made in the workplace, not on the labor market.

Nor is the problem automation, a common refrain of economists who view "skill-biased technical change" (SBTC) as the most plausible explanation for the disappearance of good jobs for members of the U.S. labor force who have only a high-school education. ${ }^{33}$ SBTC focuses on labor-market supply and demand to determine employment outcomes. But, especially where the adoption of new technologies is involved, employment outcomes in terms of pay and promotion are determined within the employing organizations, not on labor markets. In the United States the roots of the employment problem are systemic changes in employment relations related to rationalization, marketization, and globalization. The concomitant "financialization" of the resource-allocation decisions of U.S. business corporations has deepened the job-destroying impacts of rationalization, marketization, and globalization, while it has ensured that these U.S. business corporations would not invest in a sufficient quantity of the new high-value-added employment opportunities required for masses of Americans to maintain high living standards in the new global economy.

Given the dramatic changes in technology, markets, and competitors that have occurred in the world economy since the 1970s, it would be foolish to think that the secure and wellpaid employment opportunities available to members of the U.S. labor force in the three decades or so after World War II could have been sustained without substantial changes in educational attainment and employment relations. Nevertheless, the disappearance of previously existing middle-class jobs does not explain why, in a world of technological change, U.S. business corporations have failed to use their substantial profits to invest in

\footnotetext{
32 See, for example, Narayana Kocherlakota, "Back Inside the FOMC," President's speeches, Federal Reserve Bank of Minnesota, 2010; Marcello Estevão and Evridiki Tsounta, "Has the Great Recession Raised U.S. Structural Unemployment?” IMF Working Paper No. 11/105, 2011 at http://www.imf.org/external/pubs/ft/wp/2011/wp11105.pdf.

33 Daron Acemoglu, "Technical Change, Inequality, and the Labor Market," Journal of Economic Literature, 40, 1, 2002 : 772; David H. Autor, Lawrence F. Katz, and Melissa S. Kearney, "The Polarization of the U.S. Labor Market," American Economic Review, 96, 2, 2006: 189-194; Claudia Goldin and Lawrence Katz, The Race between Education and Technology, Harvard University Press, 2010; Erik Brynjolfsson and Andrew McAfee, The Second Machine Age: Work, Progress, and Prosperity in a Time of Brilliant Technologies, W. W. Norton, 2014. For our extended critique of SBTC, see Lazonick et al., "Skill Development and Sustainable Prosperity."
} 
new rounds of innovation that can create the quantity of new high-value-added jobs that a prosperous economy requires. As proponents of SBTC recognize, technological change can create high-skill jobs even as it may be eliminating low-skill jobs. ${ }^{34}$

The fundamental problem is the obsessive focus of the top executives of U.S. corporations on their companies' stock prices. It was while the old structures of secure and well-paid employment were being undermined by rationalization, marketization, and globalization, that U.S. business corporations became afflicted with financialization. The prime manifestations of financialization have been, and remain, the distribution of corporate cash to shareholders through stock repurchases, often in addition to generous cash dividends, and, incentivizing these distributions, the stock-based explosion of the remuneration of top corporate executives. ${ }^{35}$ Returning the U.S. economy to a business regime characterized by retain-and-reinvest means confronting these two foundations of corporate financialization head on.

\section{Recommissioning Employment Opportunity}

When the EEOC was launched in 1965, one could rightly assume that the governance of major U.S. corporations supported a retain-and-reinvest resource-allocation regime and that the employment norm at major U.S. business corporations was, for both blue-collar and white-collar workers, a career with one company. And indeed, in the 1960s and 1970s, significant numbers of high-school-educated blacks as a demographic group began to attain middle-class living standards by gaining access to secure and well-paid blue-collar jobs. What we have called the equal employment opportunity omission was the result of an implicit assumption that the retain-and-reinvest corporate resource-allocation regime that was in place in the 1960s, accompanied by a progressive income-tax structure, would persist over a long enough period of time that, with EEOC in place, retain-and-reinvest would do for blacks what in the immediate postwar decades it had done for the sustained upward mobility of whites.

Instead by the 1980s, beginning with the transformation of employment relations that we have called rationalization, a new ideology of corporate resource allocation known as "maximizing shareholder value" (MSV) argued that for the sake of superior economic performance, business corporations should engage in downsize-and-distribute. The election of Ronald Reagan enabled proponents of MSV, which had its origins in the freemarket economics of the Chicago School, to capture the Securities and Exchange Commission (SEC), which in November 1982 adopted Rule 10b-18 giving corporate

\footnotetext{
34 Frank Levy and Richard Murnane, The New Division of Labor: How Computers are Creating the Next Job Market, Princeton University Press, 2004.

35 William Lazonick, "Profits Without Prosperity: Stock Buybacks Manipulate the Market and Leave Most Americans Worse Off," Harvard Business Review, September 2014, 46-55.
} 
executives license to manipulate their companies' stock prices by doing massive stock repurchases. ${ }^{36}$

In the 1980s the proponents of MSV, known as agency theorists, argued that by engaging in retain-and-reinvest, managers of Old Economy corporations were misallocating corporate resources, often for their own aggrandizement-quite an ironic charge in retrospect, given how executive pay has exploded over the past three decades as senior executives have embraced MSV and the downsize-and-distribute allocation regime that it advocates. ${ }^{37}$ The problem of corporate inefficiency could be fixed, the agency theorists contended, by distributing cash to shareholders so that they could reallocate resources to their most efficient uses via the stock market, and to incentivize executives to do so, they advocated stock-based pay. Although agency theorists targeted what we are now calling Old Economy companies as the sources of economic inefficiency, the broader acceptance of MSV ideology was aided by the importance of the stock market in attracting capital and labor to New Economy companies and by the fact in the 1980s and most of the 1990s innovation was more important than speculation and manipulation in driving the stock-price performance of these New Economy companies. ${ }^{38}$

The seminal article upon which agency theorists built the case for MSV was Michael Jensen and William Meckling, "Theory of the Firm: Managerial Behavior, Agency Costs, and Ownership Structure," published in 1976. ${ }^{39}$ Trained as Chicago School economists, the coauthors were faculty members at the University of Rochester, where Jensen was a professor and Meckling was dean of the business school. In 1985, with Wall Street booming with mergers and acquisitions and the industrial heartland struggling with plant closings and permanent layoffs, the president of Harvard University and the dean of Harvard Business School succeeded in a concerted effort to recruit Jensen. Prior to 1985 no one at Harvard Business School was talking about "maximizing shareholder value." In the years after Jensen's arrival at Harvard, MSV became a mantra as it dominated MBA teaching, while, with the help of executive education programs and incentivized by stock-based pay, corporate executives embraced MSV ideology. 40

Neoclassical economic theory lacks a theory of innovative enterprise, ${ }^{41}$ but agency theorists pretended that they understood the determinants of superior corporate

\footnotetext{
${ }^{36}$ Lazonick, "Stock Buybacks”; Ken Jacobson and William Lazonick, “SEC Rule 10b-18: A License to Loot," presentation to the annual conference of the Society for the Advancement of Socio-Economics, London School of Economics, July 3, 2015.

37 Lazonick "Stock Buybacks."

${ }^{38}$ Lazonick, Sustainable Prosperity in the New Economy?, ch. 6; Hopkins and Lazonick, "The Mismeasure of Mammon".

${ }^{39}$ Michael C. Jensen and William H. Meckling, "Theory of the Firm: Managerial Behavior, Agency Costs, and Ownership Structure," Journal of Financial Economics, 3, 4, 1976: 305-360.

40 This statement is based on William Lazonick's observations while associated with Harvard Business School between 1984 and 1992. For the intellectual origins of MSV, see Joshua Weitz, "'Women, Blacks, Consumers of a Clean Environment: A Political History of the Origin of Shareholder Value," paper presented at the annual meeting of the New York State Sociological Association, September 30, 2016 (awarded the prize for "Best Undergraduate Student Paper" at the meeting).

${ }^{41}$ Lazonick, "Innovative Enterprise or Sweatshop Economics?".
} 
performance by redefining it to mean increases in shareholder value. ${ }^{42}$ In the process, agency theorists targeted government regulation as a prime cause of corporate "inefficiency." For example, in a 1983 paper, Jensen and Meckling attacked "various antidiscrimination programs which limit the employment policies of organizations and require employers to discriminate against white males and in favour of blacks, Mexicans, Indians, females, the aged, and so on," and went on to blame "wealth transfer...from the owners of the corporation (i.e. stock and bondholders) and consumers of the product, to these other groups (women, blacks, consumers of a clean environment, etc.)" for poor stock-price performance. ${ }^{43}$

The proponents of MSV argue that by making stock-based pay a major proportion of executive compensation, the incentives of corporate managers in the allocation of resources can be aligned with those of public shareholders. ${ }^{44}$ Only if the corporation's "free cash flow" is distributed (or as they put it, "disgorged") to shareholders, the MSV proponents contend, will the economy's resources be allocated to their most efficient uses. The money from the corporate coffers can be distributed to shareholders in the forms of cash dividends and stock repurchases.

Central to the MSV argument is the assumption that, of all participants in the business corporation, shareholders are the only economic actors who make productive contributions without a guaranteed return. All other participants such as creditors, workers, suppliers, and distributors allegedly receive a market-determined price for the goods or services that they render to the corporation, and hence take no risk of whether the company makes or loses money. On this assumption, the very definition of "free cash flow" includes corporate earnings that under OEBM would have been invested in training and retaining employees. And on this assumption, only shareholders have an economically justifiable claim to the "residual" of revenues over costs after the company has paid all other stakeholders their guaranteed contractual claims for their productive contributions to the firm.

By the MSV argument, shareholders are the only stakeholders who need to be incentivized to bear the risk of investing in productive resources that may result in superior economic performance. As the only "residual claimants," the MSV story goes, shareholders are the only stakeholders who have an interest in monitoring managers to ensure that they allocate resources efficiently. Furthermore, by buying and selling corporate shares on the stock market, public shareholders, it is argued, can directly reallocate resources to uses that are more efficient than investments within the corporation.

\footnotetext{
42 See, for example, Michael C. Jensen, “Takeovers: Folklore and Science," Harvard Business Review, November-December 1984: 109-121.

43 Michael C. Jensen and William H. Meckling, "Democracy in Crisis,” Centre for Independent Studies, Sydney, Australia, February 3, 1983, pp. 4-5.

44 See Michael C. Jensen, “Agency Costs of Free Cash Flow, Corporate Finance, and Takeovers," American Economic Review, 76, 2, 1986: 323-329; Michael C. Jensen and Kevin J. Murphy, "Performance Pay and Top Management Incentives" Journal of Political Economy, 98, 2, 1990: 225-264.
} 
There are two fundamental flaws with this argument. ${ }^{45}$ The first flaw is the contention that, via the stock market, public shareholders allocate resources to more efficient uses. As a general rule, they do not. Passive shareholders merely use the stock market to generate returns on their household savings to augment their incomes, often to fund their retirement. Most representative today of active shareholders are hedge-fund activists, formerly known as corporate raiders and better described as corporate predators, who seek to extract value from companies by pressuring CEOs and their boards to downsize and distribute, and where possible engage in price gouging of buyers, so that they can sell their shares at higher prices and thereby build their hedge-fund "war chests," thus increasing their financial power to extract even more value from companies as time goes on. ${ }^{46} \mathrm{MSV}$ is the ideology, now widely accepted by conservative and liberal economists alike, that legitimizes this looting of the industrial corporation.

The second flaw with MSV lies in the erroneous assumption that shareholders are the only corporate participants who bear risk. Taxpayers through government agencies and workers through the firms that employ them make risky investments in productive capabilities on a regular basis. From this perspective, households as taxpayers and workers may have "residual claimant" status: that is, an economic claim on the distribution of profits.

Through government investments and subsidies, taxpayers regularly provide productive resources to companies without a guaranteed return. As an important example, but only one of many, the 2016 budget of the U.S. National Institutes of Health (NIH) is $\$ 32.3$ billion, with a total NIH investment in life-sciences research from 1938 through 2015 of \$958 billion in 2015 dollars. ${ }^{47}$ Businesses that make use of life-sciences research benefit from the public knowledge that the NIH generates. As risk bearers, taxpayers who fund such investments in the knowledge base, or physical infrastructure such as roads, have a claim on corporate profits if and when they are generated. Through the tax system, governments, representing taxpayers in general, seek to extract this return from corporations and individuals that reap the rewards of government spending. However, tax revenues on the prospective gains from innovation depend on the success of innovative enterprise while, through the political process, tax rates on those gains are subject to change. Hence, for both economic and political reasons, the returns to taxpayers whose money has been invested for the benefit of business enterprises are by no means guaranteed.

\footnotetext{
45 See Lazonick and 0'Sullivan, "Maximizing Shareholder Value"; William Lazonick, "Innovative Enterprise and Shareholder Value," Law and Financial Markets Review, 8, 1, 2014: 52-64; Lazonick, "Stock Buybacks."

46 As an example, see William Lazonick, Matt Hopkins, and Ken Jacobson, "What we learn about inequality from Carl Icahn's $\$ 2$ billion 'no brainer'," Institute for New Economic Thinking Ideas \& Papers, June 6, 2016, at https://www.ineteconomics.org/perspectives/blog/what-we-learn-about-inequality-from-carl-icahns-2-billion-appleno-brainer. See also William Lazonick, Matt Hopkins, Ken Jacobson, Mustafa Erdem Sakinç, and Öner Tulum "U.S. Pharma's Business Model: Why It Is Broken, and How It Can Be Fixed," in David Tyfield, Rebecca Lave, Samuel Randalls, and Charles Thorpe, eds., The Routledge Handbook of the Political Economy of Science, Routledge, forthcoming.

47 National Institutes of Health, "Budget," at http://www.nih.gov/about-nih/what-we-do/budget. See also Lazonick and Tulum, "US Biopharmaceutical Finance."
} 
Workers regularly make productive contributions to the companies for which they work through the exercise of skill and effort beyond those levels required to lay claim to their current pay, but without guaranteed returns. ${ }^{48}$ Any employer who is seeking to generate a higher-quality, lower-cost product knows the profound productivity difference between employees who just punch the clock to get their daily pay and those who engage in learning to make productive contributions through which they can build their careers and thereby reap future returns in work and in retirement. Yet these careers and the returns that they can generate are not guaranteed, and under the downsize-and-distribute resourceallocation regime that MSV ideology has helped put in place, these returns and careers have been, in fact, undermined.

As risk bearers, therefore, taxpayers whose money supports business enterprises and workers whose efforts generate productivity improvements have claims on corporate profits if and when they occur. MSV ignores the risk-reward relation for these two types of economic actors in the operation and performance of business corporations. Instead it erroneously assumes that shareholders are the only residual claimants.

The irony of MSV is that the public shareholders whom it holds up as the only risk bearers typically never invest in the value-creating capabilities of the company at all. Rather, they purchase outstanding corporate equities with the expectation that while they are holding the shares dividend income will be forthcoming and with the hope that when they decide to sell the shares the stock-market price will have risen to yield a capital gain. Following the directives of MSV, a prime way in which the executives who control corporate resource allocation fuel this hope is by allocating corporate cash to stock buybacks to pump up their company's stock price. Senior executives "disgorge" this cash flow, not for the sake of efficient resource allocation, but rather for the sake of increasing their own stock-based pay. 49

MSV legitimizes the corporate resource-allocation incentives and practices that have since the 1980s concentrated income among the richest 0.1 percent of households, including those of senior corporate executives. By the same token, MSV has resulted in the erosion of middle-class employment opportunities in the United States. ${ }^{50}$ African Americans have been victims of this downsize-and-distribute resource-allocation regime, but so too have white, Hispanic, and other Americans who lack college educations. The combination of MSV and NEBM makes employment far less secure and pay much more variable for those Americans with college educations as well. In the marketized, globalized, and financialized economy of the twenty-first century, even a higher education does not make one immune to the ravages of downsize-and-distribute.

MSV is not simply a business ideology. It is a product of neoclassical economics which, in both its conservative and liberal versions, views the market as the mode of efficient

\footnotetext{
48 Lazonick, Competitive Advantage on the Shop Floor; Lazonick, "The Theory of Innovative Enterprise."

49 Hopkins and Lazonick, "The Mismeasure of Mammon."

50 Lazonick, "Labor in the Twenty-First Century."
} 
resource allocation and ignores the central role of business corporations in the success or failure of the economy to invest in productive employment opportunities. In our view, MSV is the most damaging ideology ever propounded by the economics profession. Any policy agenda that is concerned with employment opportunity must both engage in new economic thinking and take steps to put an end to the economic-and political-disaster that MSV has wrought.

From the "fifty years after" perspective that we have offered, there are four policy changes that can transform the governance of U.S. corporations to recreate an innovative economy based on retain-and-reinvest:

1. Ban stock buybacks: Households as savers who allocate some of their assets to corporate stocks can get an income from dividends if and when a retain-and-reinvest company can afford to pay them, and then, as a result of well-managed investments in productive capabilities, expect to be able to sell the shares at higher prices if and when they want to readjust their financial portfolios. Stock buybacks that are permitted, and indeed encouraged, by the SEC under Rule 10b-18 are simply a means of manipulating stock prices to reward those who are positioned to time their share selling, including the senior corporate executives who make the buyback decisions, hedge-fund managers who apply pressure for buybacks, and investment bankers who help engineer them. Stock buybacks make a mockery of the SEC's stated mission "to protect investors; maintain fair, orderly, and efficient markets; and facilitate capital formation." ${ }^{1}$ SEC Rule 10b-18 should be rescinded, and stock buybacks should be banned.

2. Restructure corporate executive incentives: The vast majority of the pay of senior corporate executives is stock based, rewarding them for selling corporate shares in the wake of rapid stock-price increases, often assisted by buybacks and other forms of market manipulation. The stock prices of publicly listed companies are driven by a combination of innovation, speculation, and manipulation, and increasingly executives have been rewarded for value-extracting manipulation rather than value-creating innovation. Reward senior executives for generating high-quality products at low unit costs (the economic definition of innovation that results in competitive goods and services), and tie their remuneration to the increased employment stability and enhanced earnings of the broad base of employees whose skills and efforts helped to generate those products.

3. Transform corporate governance: Through government investment in physical infrastructure and the society's knowledge base, households as taxpayers risk their money in helping to fund business investment in productive capabilities. Through the application of their skills and efforts, households as workers risk their time, and hence livelihoods, in helping to generate competitive products that may result in future business profits. On these bases, households as taxpayers and workers should have representation on the boards of directors of publicly listed companies. Households as

51 https://www.sec.gov/about.shtml 
shareholders should also have board representation, but it should be as savers. They do not generally invest in the productive capabilities of the companies whose shares they hold, and hence should not be called "investors," as is typically the case. Parties who have actually invested in a company's productive capabilities should have board representation. But speculators and manipulators who make their money by buying and selling corporate shares, and hence do not make productive investments and would be in positions to abuse insider information, should not be permitted to be on boards.

4. Recommission employment opportunity: Fifty years after the creation of the EEOC, it is clear that as an actor in the economy, the government cannot simply monitor equal employment opportunity and hope that equal employment opportunity will be the result. At the same time, federal, state, and local governments play major roles in investing in the physical infrastructure and knowledge base that make a productive business system possible. There is a lot of political rhetoric of the government putting in place policies that will create good jobs, but in the era of the financialized corporation most of the taxpayers' money that governments spend will not have that impact. Indeed, given the current state of the U.S. economy, the notion of equal employment opportunity is a race to the bottom, and those who lack employment opportunity know it. For the sake of the majority of Americans-black, white, and other-for whom the world's richest economy is not delivering twenty-first century employment opportunity, there is an urgent need to rethink in a fundamental way how, in theory and in practice, governments, businesses, and households interact in generating stable and equitable economic growth. 